\title{
The Interrelation Between the Results of Socio- Economic Development and the Parameters of the Structure of the Financial System of Russia
}

\author{
Lebedev A.V. ${ }^{1}$ Razumovskaya E.A. ${ }^{2,3^{*}}$ \\ ${ }^{1}$ Qualifications and competencies development fund in the Ural region, Yekaterinburg, Russia \\ ${ }^{2}$ Ural Federal University named after the first President of Russia B.N. Yeltsin, Yekaterinburg, Russia \\ ${ }^{3}$ Ural state university of economics, Yekaterinburg, Russia \\ ${ }^{*}$ Corresponding author. Email: rasumovskaya.pochta@gmail.com
}

\begin{abstract}
The subject of the study is the structural parameters of the financial system, on the basis of which it is possible to assess the quality of its structure. The purpose of the study is to attempt to verify the hypothesis, that there is an interrelation between the structure of the Russian financial system and the results of socioeconomic development. The study methodology was compiled by the OECD international methodology and data from the Central Bank of the Russian Federation, based on which the authors analyzed the structure of the financial system of Russia. The main results: 1). author's interpretation of macroeconomic identity, reflecting factor sources of economic growth is presented; 2) the value of capital as a financial parameter, subject to transformation under the influence of advanced digital technologies is disclosed; 3 ) author's factors for conducting a qualitative analysis of the structure of the financial system are developed, taking into account the specifics of the Russian national economy, one of which is intended to reflect the level of financial digitalization - an actual indicator of financial potential. Conclusions. Given the current discussion opinions on the influence of the structure of the financial system on economic growth, the authors believe, that in the continuation of this study, it is required to refer not only to international methods, but also create domestic scientific developments, which are 5-9 factors.
\end{abstract}

Keywords: socio-economic development, structure of the financial system, quality factors of the financial

system

\section{INTRODUCTION}

New world studies in the assessment of the influence of the structure of the financial system on economic growth are carried out in different countries: from post-Soviet to new industrial $[5 ; 7 ; 9 ; 10 ; 14]$, while approaches to studying the structure of the financial system are relatively new to domestic financial science, but they carry serious theoretical and practical potential. According to the authors, this potential consists in searching and substantiating mechanisms and tools for financial regulation of economic and social processes in the national economy. Factor sources of socio-economic development are terminal in their contribution to socio-economic development, while the financial structure is a certain organism, the optimization of which can stimulate economic growth without additional financing. The scientific basis in the search for sources of economic development is historically determined by three basic theoretical concepts:

1. C. Wicksell function, which was later verified on the basis of statistical data by C. Cobb and P. Douglas in studies of production theory: $\mathrm{y}=\mathrm{F}\left(\mathrm{A}, \mathrm{L}^{\alpha}, \mathrm{K}^{\beta}\right)$. The function reflects the empirically proven dependence of the volume of output on the costs of production factors - labor and capital, but more important than the initial influence the accelerator (A), as well as the "quality" of these factors. In relation to the labor factor (L), quality means productivity, and in relation to capital $(\mathrm{K})$, the authors propose to calculate its properties - cost, exposure to risks, liquidity and quantity.

2. The stationary condition of the R. Solow economy, which basically also has the function of C. Cobb and P. Douglas: $\mathrm{f}(\mathrm{k})=(\mathrm{n}+\mathrm{g}+\delta) \times \mathrm{k}$, where $\mathrm{n}$ is the rate of change of the number of employees; $g$ is the rate of technological progress; $\delta$ is the amount of savings, that determines the amount of investment; $\mathrm{k}$ is the capital investment.

3. Macroeconomic identity: $\mathrm{Y}=\mathrm{C}+\mathrm{Inv}+\mathrm{Gv} \pm \mathrm{Nex}=\mathrm{ASt}$ $=\mathrm{A} \times \mathrm{Kt}$, from which, after simple transformations, the equation is obtained:

$\Delta \mathrm{Y}=\mathrm{Yt}-\mathrm{Yt}-1=\mathrm{A} \times \Delta \mathrm{K}=\mathrm{A} \times \mathrm{I}$

The presented functions reveal the socio-economic development, which are ultimately determined by the volume of available investments. The source of the latter is temporarily free funds, that is, savings, the role of which 
reflects functions taking into account the Keynesian theory: $\Delta \mathrm{Y}=\mathrm{Yt}-\mathrm{Yt}-1=\mathrm{k} \mu \times \Delta \mathrm{I}=1 /((1-\mathrm{mpc})) \times \Delta \mathrm{I}$

The given functional constructions contain sources of economic growth - both financial (capital, investment, savings) and economic (labor). A feature of all these sources is their physical extremity. So, labor resources can form a contribution to socio-economic development in two ways:

1. Quantitative - i.e. extensively, when an increase in the number of employees allows to produce more products. Of course, this method is physically terminal — the labor market is limited, which is especially characteristic of developed countries where demographic trends are known. 2. Qualitative - i.e. intensively, when production growth is achieved by increasing labor productivity (by improving skills, raising the intellectual and physical qualities of workers) and equipping labor with other factors of production (mainly technology). Further training of workers and labor equipment cannot also increase endlessly: one worker, even the most capable and skillful one, cannot become more and more effective at different or identical rates [13]. Obviously, this conclusion also applies to the "land" factor in the traditional interpretation: the productivity in agriculture was disclosed by F. Quesnay in his economic table, which shows the place of land as a source of value added. Later, D. Ricardo and other representatives of the pessimistic classical political economy showed the exhaustibility of the land factor when using new goods in the production process and the need to invest in its restoration.

The use of the "land" factor in other sectors (construction, for example) is also limited - the concept, introduced by A. Marshall, is the "structure limit" and the concept, that allows characterizing the ability of the "land" to bring different income depending on its properties - "quasi-rent ". The modern interpretation of the profitability of the "land" factor correlates with the qualitative characteristics of real estate objects, which, being fixed assets or investment objects, make it possible to draw income from their use. To a large extent, however, the profitability of land is determined, along with its qualitative characteristics, by the capital, invested to improve and maintain the quality of land as a factor of production.

In this regard, the question of finding ways to increase the rate of economic development in the long term inevitably arises: due to which the productivity of labor and land factors can continue to grow?

The authors are convinced, that the answer consist in the capital factor, the increase in the raising of which can occur theoretically without restrictions, since it is potentially less exhaustive. Indeed, financial resources can be raised in a wide range both by their sources and by the properties, listed above: risk, cost, liquidity (conversion) opportunities from one form to another. An analysis of the capital structure of any entity, even the national economy, can be carried out on the basis of the model of the weighted average capital cost by F. Modigliani and M. Miller, created in the 1950s. Despite the fact, that modern conditions are significantly different from the previous ones even in the USA, for the economy of which the model was created, and the fact, that many of the assumptions of the model are little realistic, the authors propose its reconstructed modification to the following form:

$$
\mathrm{WAC}=\sum_{i=1}^{n}\left(w_{i} \times k_{i}\right)
$$

where: WAC is the weighted average capital cost, wi is the share of capital, raised from the i-th source under certain conditions; $k i$ is the cost of the $i$-th source.

In relation to theories of socio-economic development, this model means, that it is possible to raise any amount of capital (though not endless), which can stimulate economic growth in different ways. For the national economy as an entity, these can be borrowed sources - tranches of government bonds - which can be converted, prolonged and in other ways change the conditions for raising capital. In practice, these can be multi-currency borrowings (euro bonds or foreign bonds), with different security. The restriction on this type of source of financing is the country's creditworthiness, its position and quota in the IMF (International Monetary Fund) in special drawing rights (SDR).

The opinion of J. Schumpeter, which received worldwide recognition after the publication of his work on economic cycles and their causes back in the 1930s should be obviously recognized as one of the branches in the study of financial sources of economic growth [15]. For a long time, and today, the Schumpeterian concept remains relevant and is confirmed in modern financial processes.

\section{STUDY METHODS}

The discussion on the search for sources of socioeconomic development became active at the end of the twentieth century based on the use of extensive empirical data, that became available. So, R. King and R. Levine managed to show the presence of a definite and stable relationship between the level of development of the financial system and long-term rates of economic growth [12].

The aspect of modern studies is increasingly focused on financial indicators - mainly on the state of the parameters of the financial system. The most significant results of these studies are the following:

1) the level of development of the financial system influence economic development; at the same time, in the aspect of cause-and-effect relationship, it is the development of the financial system that is the cause;

2) the financial system is much more subject to change, than the real sector, but its functioning is uneven: the financial market is more dynamic, than the banking system, and as the economy develops, the financial system becomes more dependent on the state of the financial market.

Studies of the last two decades formed two main messages, on which the authors consider it reasonable to build further study:

1. The development of the financial system is assessed by indicators of "financial depth", accessibility, efficiency 
and stability of financial institutions and financial markets. These assessment indicators are determined by the matrix characteristics of the financial system of the " $4 \times 2$ " or " 3 $\times 2$ " format. Based on the " $4 \times 2$ " matrix, the World Bank (WB) Global Financial Development Database (GFDD) is built. The " $3 \times 2$ " matrix does not provide for a separate category of indicators of financial stability; it is used as the basis for the Financial Development Index (FDI) by the International Monetary Fund (IMF).

2. An analysis of the linear relationships between financial depth and the results of socio-economic development is complemented by the conclusion, that this relationship is non-linear. In particular, J.L. Erkand, G. Burkes and G. Panizza [4] proposed a hypothesis of the effect of the socalled "too much finance" effect, according to which the level of development of the financial system on the growth of the economy has a positive effect, with reaching which financial depth begins to negatively affect the economy. Current performed studies show, that a certain threshold bound, after which financial resources become "too much", is the level of gross credits in the amount of $69 \%$ of GDP [1]. And in the range of the ratio of the value of credits to GDP from 80 to $100 \%$ and higher in countries, such as the USA, Great Britain, Spain, Portugal, Ireland, Iceland and others, the exposure of national economies to negative external shocks significantly increases: it is these countries that suffered to a greater extent during the global financial crisis of 2007-2009.

Using the results, obtained using semi-parametric regressions, made it possible to calculate the average threshold value of the excess of financial resources at the level of $76 \%$ of GDP, with a confidence interval from 69 to $90 \%$ of GDP [1].

Other studies confirmed, that the dependence of economic growth on the level of development of the financial system is determined by the level of "financial depth". As indicators of financial depth the following ones were used [1]:

1. The value of private sector credits in relation to GDP. This factor can be recognized as an indicator, that adequately reflects one of the financial sources of economic growth, for the obvious reason - changes in the volume of private sector financing out of credit resources can really affect its contribution to economic growth.

2. The share of capitalization of the securities market in relation to GDP. From the basic course of financial disciplines it is known, that the increase in the capitalization of companies, forming the financial sector (as well as the capitalization of companies in the real sector), cannot be included in GDP due to the fact, that the growth in the market evaluation of the value of any company does not lead to a growth in its production, which forms the very value added, that is included in GDP, in accordance with the methodology of the system of national accounts.

3. The share of value added of the financial sector in GDP. The authors cannot agree with this indicator, since there is an ambiguous interpretation of the contribution of the financial sector to GDP: what should be considered as such? If talking about financial transactions, that bring income to participants in the financial market, this indicator cannot be included in GDP as not creating, but only redistributing the existing value added, created in other sectors of the national economy, for the same reason as indicated above in cl. 2 .

The practically obtained average estimates of indicators of financial depth, at which the financial system begins to negatively affect socio-economic development in the member countries of the Organization for Economic Cooperation and Development (OECD) are as follows:

- the value of credits, granted to the private sector, is over $60 \%$ of GDP;

- the share of capitalization of the securities market to GDP in the range from 64 to $80 \%$.

The source does not give the value of the third indicator, which convinces the authors of the validity of the above about the inadmissibility of raising the question on the inclusion in GDP of the value added, created in the financial sector of the national economy (any state).

The degree and nature of the influence of the level of development of the financial system on the socioeconomic results of the national economy has significant practical potential, which can and should be taken into account, when building a state financial policy to optimize the institutional and infrastructure structure of the financial system, and which the authors consider it appropriate to supplement with other indicators, reflecting the specifics of Russian national economy and the structure of its financial system.

\section{RESULTS}

Turning to the analysis of the structure of the financial system of the state from the perspective of assessing its influence on the results of socio-economic development, the authors consider it necessary to clarify the concept of the structure of the financial system, based on its institutional and infrastructural structure. The degree of balance of the financial system is determined precisely by its structure as a parameter, that largely determines the rate and quality of socio-economic development of the economy. The authors propose to consider the structure of the financial system as a set of financial institutions, intermediaries, financial mechanisms, instruments and financial transactions, that mediate financial relations and allow these relations to develop.

There are other approaches to determining the structure of the financial system, based on a bit different terminology the financial structure. So, E. Demirgyuch-Kant and R. Levine [8] gave a fairly general definition of the financial structure "... the financial structure is a combination of financial instruments, markets and intermediaries, operating in the economy." This definition, according to the authors, corresponds to the short concept of the financial system, but not its structure - the latter suggests some kind of component nature of the constituent elements. In addition, one could pay attention to the absence of an indication of the nature of the "combination" 
of financial instruments, markets and intermediaries and the ultimate purpose of this combination.

The basis of the conceptual presentation of the financial structure of F. Allen and D. Gale is the results of their comparative analysis of empirical data for Germany, Japan, the United Kingdom and the United States. In accordance with the results, F. Allen and D. Gale formulated the following definition of financial structure: "... the ratio of banks and markets, characteristic of ... the national economy, with a different combination, designed to provide ..." acceptable results of economic activity [4]. The authors consider this definition functionally oriented, since it shows the ultimate purpose of the existence of the financial structure of the national economy. The refinements of F. Alain and D. Gale reveal the functionality of the subjects of the financial structure banks and markets, consisting in the provision of financial services, as well as its important property - depending on the evolutionary stage of development, experienced by the economy, the latter requires differentiated combinations of financial services. Otherwise, the financial system (which, obviously, has a certain structure) will not be able to ensure proper economic growth. It is possible to agree with this position, with the exception of one very formal point - the absence of a clear distribution between the concepts of "financial structure" and "financial system", on which the authors insist on principle.

These approaches to the definition of "financial structure" can be used to clarify the definition of the concept of "structure of the financial system" and assess the influence of the latter on the results of socio-economic development, which, in turn, can serve as the basis for the formation of a balanced state policy, serving as an instrument of financial regulation socio-economic development of the country. This important belief is based on three key aspects:

1) the structure of the financial system should be an independent indicator of the ability of the financial system to stimulate economic growth, which means, that the state represented by monetary authorities can and should provide the optimal format for the structure of the financial system;

2) under the influence of cyclicity and a number of other geo-economic factors, the sensitivity of the national economy changes to the level of development of the banking sector and the financial market, which also means the need for state regulation of the financial system in aspect of its structural composition, while the mechanisms and instruments of state policy in this direction must be constantly improved;

3) the implementation of processes, associated with the transformational optimization of the institutional and infrastructural design of the financial system, requires significant costs.

A number of researchers have similar views in assessing the influence of the structure of the financial system on the results of socio-economic development. Contradiction arise only in the apparatus of such an assessment: this may be the ratio between the volumes of elements of the financial system - the banking sector and the financial market. Depending on the conditions of the analyzed economy or the initial structure of its financial system, the ratio between the non-banking sector and the financial market can be used. Langfeld and Pagano conducted study in this format and compared [12]:

1) banking assets of commercial banks and the total capitalization of the stock and bond market; as a result, an indicator was obtained - the banking market factor $\left(\mathrm{k}_{\mathrm{bm}}\right)$ this is an important indicator of the structure of the financial system is calculated by the authors according to Russian data (figure 1), based on the existing methodology of Langfeld and Pagano [12]:

$\mathrm{k}_{\mathrm{bm}}=\frac{\text { Assetsof commercial banks, \%GDP }}{\text { Capitalizaion of the stock market and corporatebonds,\% GDP }}$

2) change in debt on long-term credits in rubles and the value of corporate bond debt issue - debt financing factor $\left(\mathrm{k}_{\mathrm{df}}\right)$ is obtained:

$\mathrm{k}_{\mathrm{df}}=\frac{\text { The increasein the company's debt on long }- \text { term rubleloans }}{\text { Issueof corporatebondsof the non }- \text { financial sector }}$

The authors believe, that for a full and complex assessment of the state of the structure of the Russian financial system, it is advisable to supplement these indicators with others, included in the World Bank methodology, developed by E. Demirgüç-Kant [DemirgüçKunt A., Levine R., 2012], according to which the authors calculated the factor of the structure of the Russian financial system (figure 1) as the ratio of credits, received by the private sector, to the volume of trade in the financial market $\left(\mathrm{k}_{\mathrm{fss}}\right)$ :

$$
\mathrm{K}_{\mathrm{fss}}=\frac{\text { Loansto the privatesectorof the CB,\% GDP }}{\text { Volumes of trade in thefinancial market,\% GDP }}
$$

The indicators, calculated using the presented formulas, can serve as a platform for further studies to substantiate the model of the influence of the structure of the financial system on the results of socio-economic development. Figure 1 shows the comparative dynamics of indicators of the state of the Russian financial system and its development rate (GDP is accepted as a key indicator of the state of the national economy). 


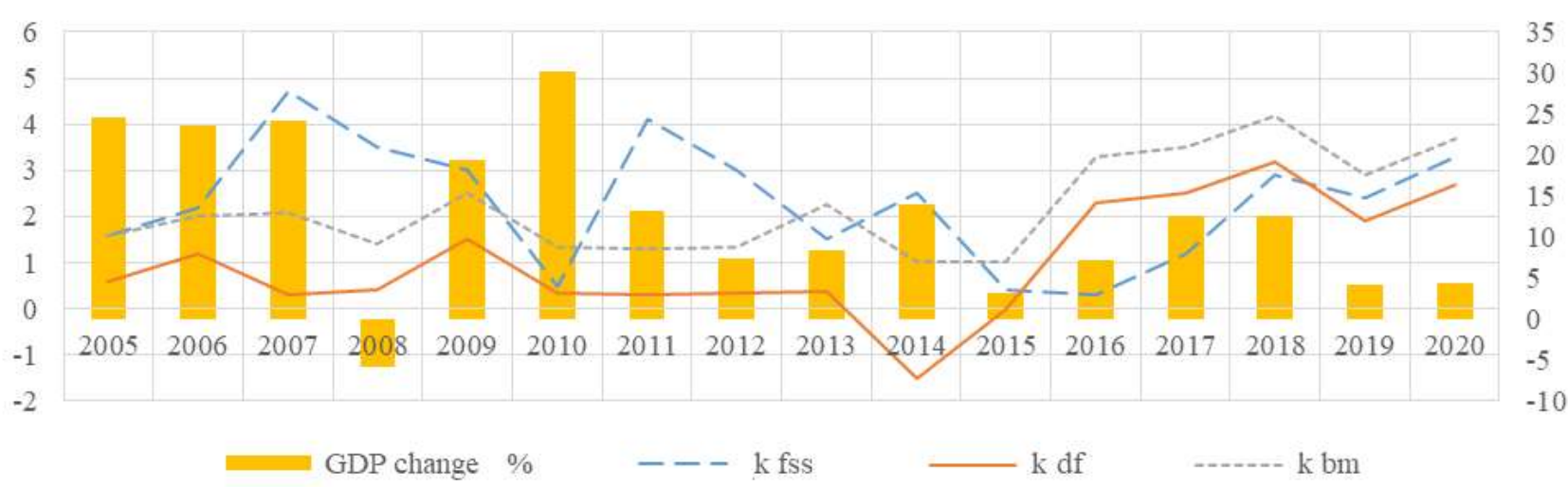

Figure 1 Comparative dynamics of indicators of the structure of the financial system and GDP of the Russian economy, \% [3]

As can be seen from figure 1 , the trends in financial indicators and the dynamics of GDP in 2010 and 2015 show especially clearly, that the economy is recovering with the reduce of debt burden on loans and bond loans. This circumstance allows to state, that the structure of the financial system has a direct influence on the socioeconomic development of the national economy of the Russian Federation.

Despite the authoritativeness of the considered methods, allowing to assess the structure of the financial system, the authors consider them incomplete and insufficiently reflecting the specifics of Russian conditions: the state's share in the national economy and in the financial system. In this regard, the authors propose to introduce the following indicators:

1. The factor of nationalization of the financial system (or financial dependence) - as the ratio of capitalization (or assets) of state banks to GDP $\left(\mathrm{k}_{\mathrm{fd}}\right)$ :

$$
\mathrm{K}_{\mathrm{fd}}=\frac{\text { CapitalizaionSB }}{\text { Grossdomestic product }}
$$

2. Debt distribution factor: the volume of lending (increase) of the private sector to the issue of public debt;

$$
\mathrm{K}_{\mathrm{dd}}=\frac{\text { PrivatesectorloansCB, } \% \text { GDP }}{\text { Emission of publicdebt, } \% \text { GDP }}
$$

3. The efficiency factor of the use of credit financing, as the ratio of the total capitalization of private sector companies to the debt sources of their financing;

$$
\mathrm{k}_{\mathrm{lfe}}=\frac{\text { Capitalization of privatesectorcompanies, } \% \text { GDP }}{\text { Volume of debt financing of the privatesector,\% GDP }}
$$

4. Factor of financing companies of the non-financial sector through bank credits and the issuance of debt securities to GDP.

$$
\mathrm{k}_{\mathrm{nfsf}}=\frac{\text { Capitalization of non }- \text { financial companies, } \% \text { GDP }}{\text { Total debt financing of the non }- \text { financial sector, } \% \text { GDP }}
$$

The proposed factors require discussion in the scientific community before calculations will be carried out on them, however, the authors are convinced, that their use can be productive in both theoretical and applied aspects. Assessment of the influence of the structure of the financial system on the results of socio-economic development should be carried out according to many indicators, what for the spectrum of proposed factors is designed, each of which reflects a key macroeconomic parameter - gross domestic product (GDP), as an indicator of the state of the national economy.

\section{DISCUSSION}

The key problem, that is reasonably paid attention to when analyzing the influence of the structure of the financial system on the results of socio-economic development is the opinion [4] about the accelerated development of the financial system - "financialization", which is likely to increase the range of opportunities and directions of economic growth. However, the implementation of both opportunities and, to a large extent, directions, depends on the qualitative parameters of the financial system:

- efficiency;

- stability;

- availability.

The main driver of accelerating of socio-economic development, based on not factor dynamics, but on the basis of using the potential of the financial system structure, according to the latest international studies, is increase in the availability of financial services and services, as well as the efficiency of financial institutional and infrastructure architecture [2].

Other authoritative opinions are, that along with the indicator of financial depth, the parameters of the financial sector development, used in the calculation of the financial development index, also influence socio-economic development [1]. Empirical studies confirmed the influence of the level of financial development on economic growth. 
As international and some domestic studies show, the influence of the structure of the financial system on socioeconomic development consists of the negative influence of a bank credit and the positive influence of the stock market. At the same time, it is necessary to take into account the differentiation of credits, since in the studies of B. Konede, O. Denk and P. Hoeller, the negative influence of the growth of bank lending on socio-economic development is up to two times stronger than other sources of financing [6]. It means, that in order to stimulate economic growth, it is necessary to use mechanisms to balance the structure of the financial system in order to level the dominance of the banking segment and support the development of the financial market.

\section{CONCLUSIONS}

Summarizing the results of this study, the authors consider it worthwhile to fix on an important circumstance: in relation to Russian conditions, it is really difficult to draw categorical conclusions about the current state and unambiguously predict trends in changes of the structure of the Russian financial system and how they will reflect on the results of the socio-economic development of the national economy. Obstacles to this exist, in particular: the real influence on the financial system and the entire economy of the so-called natural factors - a significant share of raw materials in exports, the demographic situation (population decline), an insufficiently competitive level of labor productivity and some others. These factors are objectively unfavorable, however, whether they can really be improved by transforming the structure of the financial system is a discussion question.

The most important conclusion, which the authors especially emphasize, is that in studies to assess the influence of the structure of the financial system on the results of socio-economic development, it is required to rely both on existing methods in world practice and on the creation of domestic scientific developments in this direction. The authors propose to consider the coefficients 5-8 as a scientific development.

The authors consider further studies appropriate to carry out in line with the influence of financing sources (both banking and raised in the financial market), as characterizing the structure of the financial system on the results of socio-economic development.

\section{REFERENCES}

[1] Yu.A. Danilov, D.A. Pivovarov, Voprosy ekonomiki. 2018. № 3, s. 30-47.

[2] A.V. Lebedev, Ye.A. Razumovskaya, Finansovoye regulirovaniye vosproizvodstvennykh i investitsionnoy protsessov $\mathrm{v}$ natsional'noy ekonomike Rossii v nachal'nyy period rynochnykh reform, EiMSU № 3, 2019, s. 68-76.
[3] Ofitsial'nyy sayt Tsentral'nogo Banka RF, Elektronnyy resurs. Dostup na 11.10.2019 g.: https://www.cbr.ru.

[4] J.-L. Arcand, E. Berkes, U. Panizza, Too much finance? IMF Working Paper, 2012, no. WP/12/161 // Электронный ресурс. Доступ на 11.10.2019 г.: https://www.imf.org/external/pubs/ft/wp/2012/wp12161 .pdf.

[5] S. Chakraborty, T. Ray, The development and structure of financial systems, Journal of Economic Dynamics and Control. Volume 31, Issue 9, September, 2007, pp. 2920-2956.

[6] B. Cournède, O. Denk, Finance and economic growth in OECD and G20 countries. OECD Economics Department Working Papers, 2015, no. 1223. Электронный ресурс. Доступ на 11.10 .2019 г.: https://econpapers.repec.org/paper/oececoaaa/1223en.html.

[7] V. Deltuvaite, L. Sinevičienè, Research on the Relationship between the Structure of Financial System and Economic Development, Procedia: Social and Behavioral Sciences. Volume 156, November, 2014, pp. 533-537.

[8] A. Demirgüç-Kunt, R. Levine, Financial structure and economic growth: Perspectives and lessons, 2012, Электронный ресурс. Доступ на 11.10.2019 г.: https://www.landecon.cam.ac.uk/research/real-estateand-urban-analysis/centres/ccepp/copy_of_ccepppublications/wp06-05.pdf

[9] O.E. Ergungor, Financial system structure and economic growth: Structure matters, International Review of Economics \& Finance. Volume 17, Issue 22008, pp. 292-305.

[10] B. Fîrcescua, Crises Effects on Financial System Structure in some Post-Communist Countries, Procedia: Social and Behavioral Sciences. Volume 5812, October, 2012, pp. 444-453.

[11] R. G. King, R. Levine, Finance and growth: Schumpeter might be right. Quarterly Journal of Economics, 1993, vol. 108, No. 3, pp. 717-737.

[12] S. Langfield, M. Pagano, Bank bias in Europe: Effects on systemic risk and growth. ECB Working Paper, 2015, no. 1797. Elektronnyy resurs. Dostup na 11.10.2019

g. https://econpapers.repec.org/paper/ecbecbwps/2015179 7.html. 
[13] A.V. Lebedev, E.A. Rasumovskaya, Financial Regulation in the Initial Phase of Market Reforms in Russia and Its Impact on Subsequent Economic Development, The 2nd International Conference on Education Science and Social Development (ESSD), Changsha, China, on July 20-21st, 2019. Advances in Social Science, Education and Humanities Research, volume 298, pp. 559-564.

[14] D. Simion, M. Stanciu, S. Armăşelu, Correlation Analysis Between Structure Financial System and Economic Growth in Romania // Procedia: Economics and Finance. Volume 32, 2015, pp. 1332-1341.

[15] J.A. Schumpeter, The Theory of Economic Development, Harvard Economic Studies, 1934. 255 p. 